\title{
Conceptual Framework for the Strategic Management
}

\author{
Dilavar Karimli, \\ Management Department, Ca'Foscari University of Venice, Azerbaijan. \\ Advisor: Khalid Cavadov, UNEC.
}

\begin{abstract}
This study aims to reveal the development of strategy and strategic management thinking, which has become even more important in today's intensely competitive environment, and the direction of current research issues in strategic management issues. In this framework, a literature review has been made to make comments and reach new syntheses by examining the subject with a broad and deep perspective in our study. It has been ensured that the sources related to the subject of the article are reviewed, opinions, attitudes, and descriptions are found. In this article, the pioneers of strategic management thought and philosophy from the past to the present and the historical development process, the strategic management schools and research issues that have emerged until today, have been tried to be revealed through a literature review. In our study, the progress and developments provided by strategic management thinking have been examined.
\end{abstract}

Keywords: Management, Strategic Management

\section{INTRODUCTION}

In a highly competitive, volatile, and highly risky environment, strategy and strategic management understanding have gained more importance for businesses. In this study, the development process of strategy and strategic management thought has been examined. This study, it is aimed to present a theoretical framework for the emergence of strategic management philosophy and the historical development of strategic management thought and to determine the research topics in the literature today. Our study aims to determine the basic questions and issues in strategic management together with the development process of strategic management by scanning the literature. A theoretical and empirical analysis of the pattern of the strategic management field and the progress in the field of strategic management has been made. It is to reveal in which sub-areas strategic theories and researches are carried out and the direction of research carried out in the academic field.

In our study, independent scientific research was carried out, the subject was examined with a broad and in-depth perspective, and a conceptual framework was created in the subject under study by analyzing and working on the variables in-depth and systematically in order to make comments and reach new syntheses. With the descriptive analysis, different opinions of different people on the same subject are presented in a way that they are obtained. In this study, with the literature review, the development of strategy and strategic management thought in the historical process has been tried to be explained with current discussion topics. In descriptive research, ongoing events are discussed and what happened is described and explained (Sönmez\&Alacapınar, 2011, p. 48). Content and descriptive analysis and qualitative analysis method were used in our research. The content analysis enables large volumes of texts to be measured with sampling and many coders (Neuman, 2016, p. 468). 
In our study, it is revealed that today's strategic management has developed as an independent field and an increase has been achieved in the studies conducted in the literature. It is aimed to present the studies that reveal the strategy and strategic management issues in the literature together and to present them collectively and to reveal the current discussions by making selective citations from the existing studies. The content analysis method was used in the literature review. The content analysis method is a method that provides the opportunity to browse many articles at once. The content analysis method enables the obtained data to be summarized, standardized, compared, or transformed into another format. In short, with content analysis, qualitative data are reduced to quantitative terms (Öğmiş, 1991, p.215).

\section{THE DEVELOPMENT PROCESS OF STRATEGIC MANAGEMENT THOUGHT}

Even though the concept of strategy has different meanings over time from past to present, it has maintained its importance by increasing. The word strategy has its own gravitational force, if we want a topic to be more meaningful than it is, we say it is 'strategic' (Yilmaz, 2009 , p.160). In today's highly competitive business environment, businesses that can make a difference and get ahead of the competition are businesses operating according to strategic management principles (Kaplan \& Norton, 2014, p.9-10). Strategic management thought undergoes a change and transformation over time depending on social, economic, and political conditions. In today's sense, it is possible to go back to the beginning of strategic thinking in the 1800s. Looking at the history of scientific management, this process II. It is seen that it gained importance after World War. The period between 1950 and 1965 is the period in which short and long term and collective planning activities were carried out. The 1970s, also known as the strategic planning period, are the period in which strategic business units stand out in businesses and strategic planning activities gain importance. The $1980 \mathrm{~s}$ is the period when competition and sector analysis activities started. The "Five Competitive Powers" model was introduced by M. Porter (1985) (Akgemci, 2013, p.13-16).

The development of strategic management thought can be considered as three main periods. It is the period of strategic planning between 1960 and 1980 , the period of competition strategy between 1980 and 1990, and the period of strategy understanding based on core competencies since the 1990s. Contemporary strategic management thought was born in the 1950s and 1960s. The first studies in this field were carried out by Chandler, Selznick, Ansoff, and Drucker (Barca, 2009, p.35). Until the early 1980s, most of the work on strategy was carried out by for-profit organizations and was applied only in the public sector or in the military field. However, today, strategy studies are carried out by all non-profit organizations (Bryson, 2011, p.12).

The concept of strategy has changed the meaning throughout history. Initially, the concept of strategy was associated with the military leader's role as a 'strategos' as a military concept (Sakl1, 2012, p.9-10). Later, it started to mean the art of general (Mintzberg et al., 1995). B.C. Sun Tzu, who put forward the concept of "martial art" in 500 years, revealed the importance of analysis by saying "it brings more account victories, less account defeats" (Wing, 1995, p. 19). This period has been a period when the strategy was handled purely in a military sense. B.C. In 450 years, at the time of Pericles, it gained the meaning of 'management success'. B.C. In 330 years; 'It meant using force and establishing a single management system to overcome competitors (Mintzberg et al., 1995). The concept of strategy was first understood as the military role and the art of military service, and then in the form of management approaches that dominate the military dimension. The strategy, understood in this context for a long time, later gained meaning in the context of political management and business management (Sakl1, 2012, p.9-10).

With the modern management approach that started in the 1960s; Three separate approaches have emerged: system approach, contingency approach, and strategic management approach. While the system approach sees the management as a whole with 
its entire environment, the contingency approach argues that there is not a single solution suitable for the structure of each organization and that the best will vary according to the situation, that is, according to the environment, technology and resources. The strategic management approach that emerged in the same period includes both the system and the contingency approach (Tümer, 1993, p.101-102).

\section{BASIC PHILOSOPHY AND IMPORTANCE OF STRATEGIC MANAGEMENT}

Strategic management thought has undergone a change and transformation over time depending on social, economic, and political conditions. The discovery of the steam engine as a new source of energy in 1765, the writing of Adam Smith's The Wealth of Nations in 1776, the French revolution in 1789 can be regarded as the cornerstones of technological and social change and strategy thought (Akgemci and Güleş. , 2010, p.6-7). In an intense competitive environment where conditions are constantly changing, strategy ideas are changing rapidly. The implementation of the strategies is evaluated in every aspect, analysis, formulation, implementation, and development in the context of the new competition. Today's strategic imperatives; it is the obligation to recognize opportunities and create value (West $\&$ Bamford, 2010, p. 7).

The philosophy of the business sets out the belief and value goals of the business. In order to continue its business activities successfully, these beliefs and values must be possessed and these beliefs and values must be reflected in the employees. The beliefs and values that make up the philosophy of the business; Being the best in the market, giving importance to details for better sustainability of the business, valuing people, offering products and services at the best quality, giving importance to real relations and friendships rather than formalism, integrity, honesty, and reliability (Yeniçeri, 2006: 52). Strategic thinking is the art of dominating the competitor and doing the same thing keeping in mind that he is trying to apply it to you (Mütercimler, 2011, p.xvii).

The strategy is made to plan the future destiny of the organization. It is necessary to think and act strategically in order not to be stuck in the day, not to be prevented by living problems, and to get rid of the charm of the current success (Yeniçeri and İnce, 2005: 463). Making strategic choices in an environment of uncertainty and the limited rationality of strategic decision-makers are seen as the basic features of strategic facts. Cross-thinking and thinking are very important in strategic management. It is necessary to know how to look at the issues from one side of the opponent on the other hand. This style of thinking, which is acquired over time, turns into cross-hatching habits, allowing you to constantly predict and evade the opponent's moves and goals, what action he aims for, how it will result, and what kind of impact it may have on you as the opponent. This situation teaches to know the opponent's goal before the opponent (Yüzbaş1oğlu, 2004, p.10).

Guessing has no place in strategic thinking; Strategic thinking does not mean opening a paper like a fortune teller (Mütercimler, 2011, p.xix). Strategic management is about the future. With strategic management, tomorrow is looked at and the future is designed. The main problem of strategic management is not what to do in the future. It is the determination of what to do now so that the events we want in the unknown and invisible future occur. According to the strategic management approach, no organization is in a vacuum. Every organization lives in the conditions surrounding it and is affected by these conditions. This environment is a variable environment. With strategic management, the external environment is looked at and the direction, framework, and rules of change are tried to be perceived (Pamuk et al., 1997, p.13-14).

Recently, there has been a striking increase in the number of studies that view the field of strategic management as critical science. According to Shrivastava (1986), strategic management is undeniably ideological. According to the thinker, strategic management undertakes the task of legitimizing the existing power structures and inequalities in resource allocation within organizations. Orthodox strategic management discourse, which conceptualizes strategy as a set of rational techniques that enable managing business in a 
complex environment, serves the interests of strategist senior managers who are in a privileged class position by masking the facts (Eryılmaz, 2016, p. 13).

\section{PIONEERS OF STRATEGIC MANAGEMENT AND GAINING SCIENTIFIC STATUS}

As the most influential pioneers of strategic management thinking; Peter Drucker, Alfred Chandler, Philip Selznick, and Igor Ansoff can be shown. P.Drucker's work on strategy began with his book "Concept of Corporation" published in 1946. Drucker emphasizes the importance of setting goals and working with goals. Another important contribution of Drucker is that he emphasizes the importance of knowledge and knowledge worker named as intellectual capital (Barutçugil, 2013, p.51). Businesses that successfully implement strategic management are better prepared for events. In order to be a strategy-oriented business and turn it into a permanent business, the strategy should be spread to all employees, the strategy should be known to make everyone's business and change should be managed successfully.

Mele and Guillen (2006) as the leading authors of strategic management; Chandler (1962), Ansoff (1965), Learned et al. (1965), Andrews (1971), Rumelt (1974), Mintzberg (1978), Ansoff (1979), Porter (1980), Porter (1986), Bartlett (1979), Ghoshal(1986), Wernerfelt (1984), Barney (1991), Prahalad and Hamel (1990), Nonaka (1991), Hamel (2000), Pfeffer and Sutton (2000) (Domenec\&Guillen, 2006, p. 2).

Strategic management thought has developed in the direction of progress by feeding from outside the field and then from within the field. When Neuru, Rasheed, and Natarajan (2008) divided the period during which strategic management formed the basis of the discipline into 3 sub-periods (1980-1986, 1987-1993, 1994-2000), in the first two periods external factors in the field of strategy and the last period internal factors. They determined that it developed under its influence. In the first period, the influence of authors such as Pfeffer, Lawrence, Aldrich, and Van de Ven on organization theory, an industrial organization like Schmalensee, organizational economics like Williamson, behavioral economics like Cyert and March are seen in the literature. In the second period, the influence of institutional economy and organizational theory, such as Nelson and Winter, Penrose, became more dominant. Recently, although the institutional economy and organization theories seen in the previous period continue to have their effects, the firm theories and the school-based on these resources have become the focus of strategic research (Barca\&Hızıroğlu, 2009, p. 142).

Alfred Chandler combined the coordination of management activities under the umbrella of strategy and stated that it is important for organizations to carry out comprehensive studies on their future and to make long-term decisions in these studies. Chandler argued that long-term strategies are necessary for determining the structure, direction and goals of businesses. He put forward the view that structure follows strategy (Chandler 1990). Chandler argued in his work "Structure and Strategy" published in 1962 that businesses should determine their strategies before deciding on their structures. Chandler has looked at the development of management understanding with a historical approach. In Chandler's analysis, effective organizational strategy and daily operations are distinguished. Selznick, on the other hand, argued that there is a relationship between the factors that form the internal environment of the organization and the events occurring in the external environment (Selznick 1984). Philip Selznick, in his book titled 'leadership in administration a sociological interpretation' in 1957, emphasized the necessity of harmonizing the internal factors of the organization with the external environmental conditions, which was later expressed in the concept of organizational ecology, and pioneered the development of the model known as the SWOT analysis today (Barutçugil, 2013, p. 52-53).

In the mid-1960s, Ansoff created a decision matrix by adding some basic concepts to this approach. Market penetration, product development, market development and diversity are the decision variables of this matrix. The aim here is to enable enterprises to make systematic decisions about their future in changing environmental conditions. In this 
study, he presented an analysis model named "gap-reducing actions" by drawing attention to the gap between existing (facts) and goals (planned) (Ansoff et al., 1976, p. 257).

Drucker presented the theory of management with goals. He advocated that management would be successful with well-defined goals and therefore a process such as setting, disseminating and monitoring goals should be integrated into all levels of the business (Drucker, 1954). Peter Drucker, one of the management gurus, examined some companies in his 1946 book 'Concept of the Corporation' and came to the following conclusion on 'What is the source of the success of companies? It has properties. Again, Drucker was the first person to state in the same work that its purpose is external, that is, the creation and satisfaction of customer needs, to the question of 'what is the purpose of the enterprise', which is one of the main arguments of strategic thinking (Barca, 2005, p.10).

Michael Porter, as the most influential strategy thinker of the 1980-1990 period, introduced three important and new concepts: five power analysis, generic strategies and value chain (Barutçugil, 2013, p. 74). J. Von Neumann and O. Morgenstren from Princeton University made history as the first academicians to examine the concept of management strategy with their works named "Theory of Games and Economic Behavior". In this work, the solutions of the conflicts encountered in politics, wars and business world are tried to be formalized. In solutions, the most basic criterion has been strategy development and planning (Çomakl1 et al., 2007, p.4).

In their 2001 publications, Kaplan and Norton explained how businesses can be strategydriven businesses with five basic principles; To turn strategy into operational terms, to spread the strategy to all employees, to make the strategy the daily business of everyone, to turn the strategy into a continuous process and to manage change. With this study, Kaplan and Norton defined the balanced result card, which they initially defined as performance management, as a strategic management model (Braam\&Nijssen, 2004, p.338).

We can summarize those who contributed to the development of strategic management and the years that left their mark as follows (Hussey, 1998, p.5); Stanford research institute between 1963-70, structured thinking system era with planning, 1965 Igor Ansoff's analytical approach to corporate strategy and his use of the concept of strategy in 1972, 1980 James Quinn's logical augmentation, 1982 Kenichi Ohmae strategic thinking and Thomas Peters and Robert Wareman quest for excellence 1985 Henry Mintzberg's concept of intended and realized strategies and Igor Ansoff's concept of contingency approach, 1986 Noel Tichy and Mary Devanma's concept of transformational leadership, 1987 Michael Porter's competitive advantage to corporate strategies and 1994 Gary Hammel and CK Prahalad is focused on reshaping industries to compete for the future.

\section{CONCLUSIONS}

Strategy is an effective tool for analytical thinking, predicting the future, improving management, organizational dynamism, development and positive change. In a strategyoriented business, the strategy has spread to all employees, they have been able to turn the strategy into a business and a permanent job for everyone and successfully manage their changes. Strategic management is proactive management. In the context of classical strategic management and contemporary strategic management approaches, there are two perspectives in strategy formulation; planning perspective and evolution. Strategy from a planning perspective: it is a systematic, purposeful plan or a guide for development. From the perspective of evolution, it is necessary to see strategy as important decisions that evolve over time, where the route can change, and which are made for development (Robbins, 1990, p.121-122).

Today, their strategic approach is focused on knowledge. All kinds of ways, methods, processes, resources and capabilities are of strategic importance. Continuous change and learning and strategic thinkings are current concepts and practices. According to the changing internal and external environmental conditions, those who learn and apply faster 
than their competitors will have an advantage in competition. New strategy conceptions are also changing with our ever-changing world. Conducting a successful strategy is the whole of the decisions that lead the business to the right place at the right time and in the right way by ensuring the correct use of its resources in the face of environmental changes and the behavior of competitors. A strategy that employees understand and believe in helps them develop their potential and acquire new skills.

\section{References}

[1]. Barney, J.B. (1991). Firm Resources and Sustained Competitive Advantage, Journal of Management, 17(1), 99-120.

[2]. Domenec, M. veGuillen M. (2006). The Intellectual Evolution Of Strategic Management And Its Relationship With Ethiccs And Social Responsibility, Working Paper No: 658, IESE Business School-Universty Of Navara, October, 1-22.

[3]. Drago W.A. (1997). Organization Structure And Strategic Planning: An Empirical Examination, Management Research News, 20(6), 30-42.

[4]. Eryılmaz, M.E. (2016). BirAraştırmacınınNaçizaneGözlemleri: İlgiliDergilerinEditörveHakemleriStratejikYönetimAlanıYazarlarından Ne Beklerler?, Turkish Journal of Management, 1(1), 9-22.

[5]. Hamel, G. vePrahalad, C.K. (1989). Strategic Intent, Harvard Business Review, 83(7/8), 148161.

[6]. Hamel, G. vePrahalad, C.K. (1990). The Core Competence of the Corporation, Harvard Business Review, 68(3), 79-91.

[7]. Hannan, M.T. ve Freeman, J. (1977). The Population Ecology of Organizations, American Journal of Sociology, 82(5), 929-964.

[8]. Hussey, D. (1998). Strategic Management: From Theory to Implementation, 4.Edt., Oxford: Butterworth Heinemann.

[9]. Miller, D. (1987). Strategy Making And Structure: Analysis And Implications For Performance, Academy Of Management Journal, 30(1), 7-32.

[10]. Mintzberg, H., Ahlstrand, B. veLampel, J. (1998). Strategy Safari: A Guided TourthroughThe Wilds Of Strategic Management, New York: The Free Press.

[11]. Mütercimler, E. (2011). GeleceğiYönetmekveKazanmakiçinStratejikDüşünme. 5. Baskı. İstanbul: AlfaYayınları.

[12]. Neuman, W.L. (2016). ToplumsalAraştırmaYöntemleri 2, 8.b., Çeviren: SedefÖzge, Ankara: SiyasalKitabevi.

[13]. Öğülmüş, S. (1991). İçerikçözümlemesi, AnkaraÜniversitesiEğitimBilimleriFakültesiDergisi, 24(1), 213-228.

[14]. Pennings, J.M., Hinings, C.R., Hickson, D.J. veSchneck, R.E. (1974). Structural Conditions of Intra Organizational Power, Administrative Science Quarterly, March, 19(1), 22-44.

[15]. Porter, M.E. (1998). Competitive Advantage: Creating and Sustaining Superior Performance With a New Introduction, New York: The Free Press.

[16]. Ries, A. ve Trout, J. (1997). Marketing Warfare, 1.b., New York: McGraw-Hill.

[17]. Robbins, S.P. (1990). Organization Theory: Structures, Designs and Applications, 3. Ed., Prentice-Hall, InternationalEditions, USA.

[18]. Venkatraman, N., Camillus, J.C. (1984). Exploring the Concept of Fit in Strategic Management, Academy of Management Review, 9(3), 513-525.

[19]. West, G.P. veBamford, C.E. (2010). Strategy: Sustainable Advantage and Performance, Canada: International Ed., South-Western.

[20]. Wing, R.L. (1995). StratejiSanat1, 1.b., Çev. Mehmet Sami DENKER - Sharifah M. ALSAGOFF, İstanbul: EzgiKitabevi.

[21]. Witt, B.D. ve Meyer, R. (2005). Strategy Synthesis: Resolving Strategy Paradoxes to Create Competitive Advantage, London: Thomson Learning. 